\title{
Smart Inventory System untuk Distribusi Vaksin dengan Metode Economic Order Quantity
}

\author{
Mohamad Syazimmi Hersyaputra $^{\# 1}$, Eva Faja Ripanti ${ }^{\# 2}$, Hafiz Muhardi ${ }^{\# 3}$

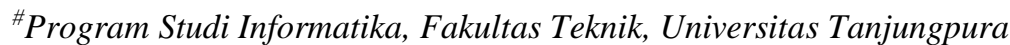 \\ Jl.Prof. Dr.H.Hadari Nawawi, Pontianak, 78124 \\ 1hersyazimmiestudent. untan.ac.id \\ evaripanti@untan.ac.id \\ 3hafizmeinformatika.untan.ac.id
}

\begin{abstract}
Abstrak- Sistem inventory adalah serangkaian aktivitas dalam melakukan proses pengelolaan data barang yang terdapat pada penyimpanan yang memiliki peran dan fungsi krusial untuk menyelesaikan permasalahan dalam mengelola, mengontrol, dan memudahkan pelaporan data barang. Sistem inventory diperlukan salah satunya untuk memanajemen persediaan stok vaksin. Saat ini manajemen persediaan vaksin pada dinas kesehatan hingga ke level puskesmas masih ditemukan permasalahan, seperti belum adanya standar perhitungan kuantitas pengadaan dan safety stock yang optimal sehingga persediaan menjadi tidak merata di beberapa wilayah yang menyebabkan terjadinya kelebihan dan kekosongan stok. Hal ini membuat pengelolaan biaya persediaan vaksin tidak efisien. Oleh karenanya, diperlukan sistem inventory yang mampu meningkatkan efisiensi pengelolaan stok vaksin yang optimal dengan meminimumkan biaya. Penelitian yang dilakukan, yaitu membangun smart inventory system menerapkan metode economic order quantity untuk mengoptimalkan persediaan dan mengimplementasikan teknologi RFID (Radio Frequency Identification) berbasis Internet of Things (IoT) untuk mengefisiensi pencatatan pergerakan stok secara otomatis. Sistem dianalisis dan dirancang menggunakan metode SDLC (System Development Life Cycle) sehingga spesifikasi kebutuhan diidentifikasi secara jelas agar dapat memecah permasalahan. Model yang digunakan adalah waterfall methodology. Selanjutnya dilakukan pengujian terhadap smart inventory system. Berdasarkan pengujian yang dilakukan menunjukkan smart inventory system memenuhi kebutuhan dalam pengelolaan stok vaksin secara efektif dan efisien dengan performance error yang terjadi hanya sebesar $1,98 \%$.
\end{abstract}

Kata kunci- Sistem Inventory, Vaksin, Economic Order Quantity, RFID, SDLC

\section{Pendahuluan}

Sistem inventory merupakan suatu aktivitas untuk melakukan proses dalam pengolahan data barang yang terdapat di dalam suatu penyimpanan sehingga dapat membantu menyelesaikan permasalahan dalam mengelola, mengontrol, dan memudahkan pelaporan data stok barang [1]. Sistem inventory memiliki fungsi serta peran yang penting dalam rantai pasokan yang membantu dalam pemantauan serta pemeliharaan produk yang disimpan [2] Penggunaan inventory system sangat berguna bagi suatu perusahaan untuk menghindari masalah kehabisan stok maupun kelebihan stok agar dapat memberikan pelayanan yang baik kepada pelanggan. Sistem inventory diperlukan untuk memanajemen persediaan bahan baku, barang, serta farmasi dan alat kesehatan. Farmasi dan alat kesehatan (farmalkes) khususnya di era jaminan kesehatan nasional saat ini menjadi kebutuhan yang paling dasar bagi masyarakat dalam bidang kesehatan. Farmalkes mencakup persediaan obat, vaksin, dan alat kesehatan. Farmalkes salah satunya dalam hal ini yaitu vaksin yang merupakan suatu produk biologis yang rentan untuk rusak terhadap suatu suhu tertentu sehingga dalam pendistribusian serta penyimpanannya diperlukan prosedur serta teknis yang tepat sesuai dengan standar yang telah ditetapkan. Oleh karena itu, dalam pendistribusian vaksin harus menggunakan prosedur cold chain [3].

Vaksin merupakan suatu antigen yang terbuat dari mikroorganisme yang telah dilemahkan atau dimatikan yang berguna untuk merangsang timbulnya kekebalan tubuh sehingga sangat penting bagi manusia [3]. Vaksinasi mengalami peningkatan yang pesat dalam beberapa tahun, hal ini dikarenakan semakin meningkatnya kesadaran masyarakat akan pentingnya kesehatan sehingga masyarakat cenderung untuk melakukan tindakan pencegahan daripada pengobatan, salah satu bentuk pencegahan yang umum dilakukan ialah melalui vaksinasi. Adanya kesadaran masyarakat yang tinggi ini, menyebabkan angka permintaan vaksin meningkat pula, oleh sebab itu perlu adanya pengelolaan inventory dan pendistribusian vaksin yang baik dan tepat sasaran.

Saat ini manajemen persediaan stok vaksin pada dinas kesehatan hingga ke level puskesmas masih ditemukan beberapa permasalahan, seperti belum adanya standar perhitungan kuantitas vaksin yang harus dipesan, kuantitas safety stock, maupun waktu pemesanan stok yang tepat [4]. Selain itu, terdapat kesenjangan yang mencolok antar daerah terkait dengan pendistribusian vaksin yang terlihat 
bahwa belum meratanya ketersediaan stok vaksin di beberapa daerah sehingga menyebabkan terjadinya kelebihan maupun kekosongan stok di berbagai fasilitas kesehatan mengingat juga bahwa stok vaksin yang didistribusikan lead time-nya kadang terlalu lama [5]. Permasalahan yang dihadapi sistem yang berjalan saat ini terjadi disebabkan beberapa hal diantaranya proses pelaporan serta pencatatan berkala yang belum baik, misalnya sering terjadinya kesalahan (error) terkait jumlah stok vaksin sesuai target yang dikorelasikan dengan jumlah kebutuhan masyarakat [6]. Pergerakan stok vaksin yang tidak terkontrol berdampak terjadinya kehilangan stok serta pendistribusian vaksin menjadi tidak tepat sasaran dan tidak efisiennya pengelolaan biaya yang digunakan. Oleh karena itu, untuk memanajemen inventory vaksin dalam mendukung pelayanan vaksinasi secara efisien diperlukan pengimplementasian suatu metode yang tepat untuk mengoptimalkan persediaan dengan menekan biaya penyimpanan sehingga dapat mengoptimalkan pengawasan pada keuangan negara, khususnya dalam pengelolaan, penyimpanan, dan pendistribusian persediaan vaksin hingga ke level puskesmas.

Terdapat beberapa metode yang dapat digunakan untuk meningkatkan kinerja sistem inventory, salah satunya ialah dengan metode economic order quantity. Metode Economic Order Quantity (EOQ) merupakan satu di antara teknik dalam proses pengadaan persediaan barang dengan mencari jumlah pesanan yang ekonomis untuk setiap kali pemesanan sesuai dengan frekuensi yang ditetapkan untuk melakukan pemesanan kembali [7]. Metode ini dapat digunakan untuk mengoptimalkan persediaan stok barang dan mendukung dalam pengambilan keputusan terkait jumlah frekuensi pengadaan serta berapa banyak stok barang yang akan dipesan pada proses pengadaan dalam satu periode. Metode ini memiliki tujuan untuk meminimalkan Total Inventory Cost (TIC). Dengan menggunakan metode ini juga dapat menekan biaya persediaan sehingga persediaan barang menjadi efisien, dapat tercapai jumlah unit pemesanan yang optimal, dan tepat sasaran.

Berdasarkan latar belakang yang diuraikan di atas, maka adanya sebuah sistem inventory diperlukan untuk mengoptimalkan persediaan stok vaksin dengan meminimumkan biaya yang dikorelasikan dengan kebutuhan masyarakat sehingga penyimpanan, pengadaan, dan pendistribusian stok vaksin menjadi efektif serta efisien dengan mengimplementasikan metode Economic Order Quantity (EOQ). Sistem inventory pada era industri 4.0 telah berevolusi berdasarkan komponen serta kinerja sistemnya menjadi suatu sistem inventory cerdas dengan menggunakan teknologi otomatisasi dengan salah satu pilar utamanya yaitu sistem berbasis Internet of Things (IoT), sehingga dalam hal ini sistem inventory yang dibangun merupakan sistem inventory cerdas (smart inventory system). Smart inventory system memanfaatkan teknologi informasi yang digunakan untuk pemeliharaan data serta informasi yang berkaitan dengan persediaan suatu barang dengan tujuan untuk memberikan efektifitas serta efisiensi antar setiap elemen dalam pasokan persediaan [8]. Smart inventory system diperlukan untuk melakukan otomatisasi proses pencatatan dan pelaporan stok barang yang akurat secara realtime dengan memanfaatkan teknologi berbasis IoT, salah satu yang umum digunakan pada sistem inventory adalah RFID (Radio Frequency Identification), RFID dapat mengidentifikasi ratusan objek melalui tag pada waktu yang bersamaan dengan jarak baca yang lebih baik dan dapat menyimpan informasi yang lebih detail [9]. RFID merupakan sebuah sistem untuk identifikasi suatu objek dengan frekuensi radio menggunakan tag atau label yang melekat pada objek yang diidentifikasi [10]. Pada penelitian ini, smart inventory system diimplementasikan pada Puskesmas Perumnas II Pontianak yang merupakan puskesmas non rawat inap dengan wilayah kerja Kecamatan Sungai Beliung, Kota Pontianak, Kalimantan Barat.

\section{Metodologi Penelitian}

Tahapan pelaksanaan penelitian ini meliputi 6 tahapan yang secara rinci metodologi penelitian dapat dilihat pada Gambar 1.

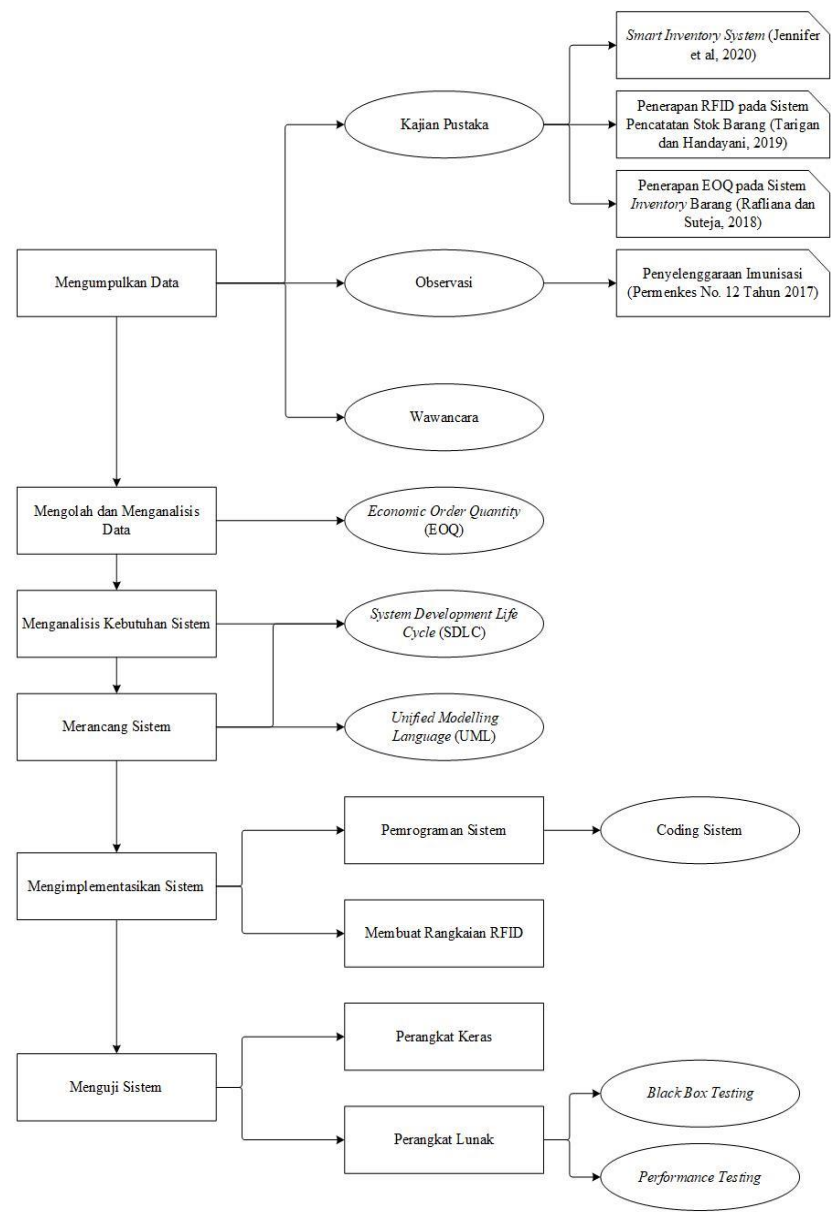

Gambar. 1 Metodologi penelitian

\section{A. Pengumpulan Data}

Pengumpulan data dilakukan melalui observasi secara langsung dan tidak langsung dengan mengamati sistem 
yang berjalan saat ini terkait dengan pendistribusian vaksin pada Puskesmas Perumnas II Kota Pontianak. Berdasarkan dari observasi yang dilakukan secara tidak langsung dengan mengamati regulasi serta kebijakan yang ditetapkan pemerintah selaku penyelenggara dari pendistribusian vaksin yang didasarkan pada Peraturan Kementerian Kesehatan Republik Indonesia Nomor 12 Tahun 2017 Tentang Penyelenggaraan Imunisasi didapatkan bahwa dalam pendistribusian stok vaksin dilakukan secara up bottom dari pusat hingga ke level puskesmas. Sedangkan untuk aliran permintaan dilakukan secara berjenjang bottom up dimulai dari puskesmas hingga ke pusat. Stok vaksin yang didistribusikan ke puskesmas didasarkan dengan permintaan resmi dari puskesmas dengan melampirkan laporan monitoring vaksin pada bulan terakhir dengan mempertimbangkan kapasitas maksimum yang dapat disimpan oleh puskesmas. Selanjutnya berdasarkan observasi yang dilakukan secara langsung pada Puskesmas Perumnas II Kota Pontianak didapatkan bahwa proses pencatatan persediaan stok vaksin pada puskesmas dilakukan secara rutin setiap bulan yang dilakukan secara terperinci menurut jumlah nomor batch stok vaksin dan tanggal kadaluarsa ke dalam laporan penerimaan vaksin atau kartu stok. Sedangkan untuk tempat penyimpanan stok vaksin pada Puskesmas Perumnas II Kota Pontianak berupa vaccine refrigerator dengan kapasitas penyimpanan sebesar 24 liter.

Selanjutnya dilakukan proses wawancara dengan petugas pengelola vaksin pada Puskesmas Perumnas II Kota Pontianak. Wawancara dilakukan bertujuan untuk mendapatkan data yang lebih teknis dan real terkait dengan proses bisnis penyimpanan serta pendistribusian stok vaksin pada level puskesmas. Berdasarkan dari hasil wawancara yang telah dilakukan didapatkan proses bisnis inventory vaksin pada Puskesmas Perumnas II Kota Pontianak sebagai berikut.

- Proses pengadaan stok vaksin pada level puskesmas dilakukan oleh satu orang petugas pengelola vaksin yang ditunjuk oleh pihak puskesmas. Petugas meminta permintaan stok vaksin per bulan ke dinas kesehatan kota. Pengiriman stok vaksin dari dinas kesehatan kota ke puskesmas dilakukan dengan menggunakan cold box untuk menjaga suhu vaksin.

- Proses pengadaan stok vaksin pada level puskesmas saat ini belum terdapat standar perhitungan yang dapat mengoptimalkan persediaan stok vaksin dan stok pengaman (safety stock) yang harus dimiliki oleh puskesmas.

- Proses pengontrolan stok (stock opname) vaksin pada vaccine refrigerator pada puskesmas dilakukan setiap hari untuk memastikan keadaan stok vaksin dalam keadaan yang baik.

- Proses pencatatan dan pelaporan stok vaksin pada puskesmas dilakukan secara manual yang dicatat dengan menggunakan laporan rekap penerimaan serta pengeluaran stok vaksin setiap bulan.
Berikut ini pada Gambar 2 merupakan diagram alir (flowchart) dari proses bisnis pada sistem inventori vaksin Puskesmas Perumnas II Kota Pontianak.

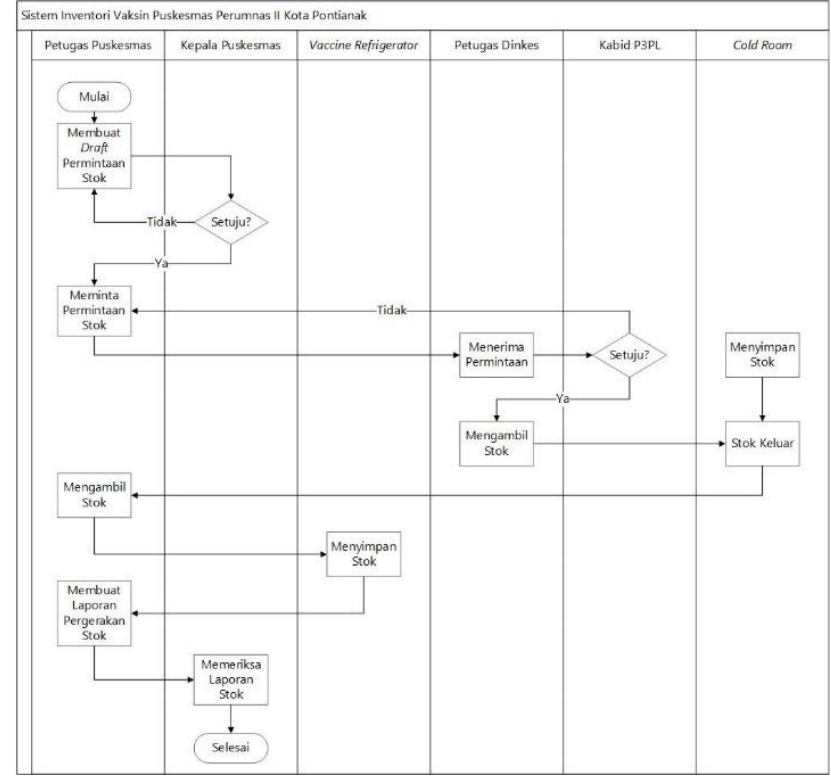

Gambar 2. Proses bisnis sistem inventori vaksin Puskesmas Perumnas II

\section{B. Mengolah dan Menganalisis Data}

Tahapan ini dilakukan setelah mengumpulkan data yang meliputi data jumlah permintaan kebutuhan vaksin dalam satu periode, biaya pemesanan vaksin, dan biaya penyimpanan vaksin untuk vaksin yang didistribusikan oleh Puskesmas Perumnas II Kota Pontianak. Kemudian data ini diolah dan dianalisis untuk mengidentifikasi jumlah pengadaan stok vaksin yang optimal, frekuensi pengadaan, estimasi perkiraan pengadaan, dan jumlah safety stock sehingga dapat meminimumkan Total Inventory Cost (TIC) menggunakan metode EOQ.

Economic order quantity adalah teknik yang digunakan dalam proses pengadaan barang untuk mengetahui jumlah pesanan yang optimal dengan mempertimbangkan biaya pengadaan, biaya persediaan, dan biaya pemesanan di awal [11]. Metode ini memiliki tujuan untuk meminimalkan total inventory cost dengan mempertimbangkan biaya pemesanan dan penyimpanan [12]. Pengendalian persediaan dengan menggunakan metode EOQ meliputi tahapan berikut [13].

- Menentukan jumlah frekuensi pengadaan dalam satu periode tertentu.

- Menghitung safety stock untuk menghindari terjadinya kekurangan stok. Safety stock ialah sejumlah persediaan yang diperlukan untuk menjaga sewaktu-waktu ada tambahan kebutuhan atau keterlambatan kedatangan barang [14].

- Menghitung jumlah Total Inventory Cost (TIC).

Dalam pengimplementasian pengendalian persediaan dengan menggunakan metode EOQ didasarkan dengan adanya asumsi bahwa kebutuhan bersifat continue (terusmenerus) terhadap pola permintaan yang cenderung stabil 
[15]. Berikut ini adalah asumsi yang digunakan pada metode EOQ.

- Kecepatan arus permintaan terhadap barang bersifat tetap dan terus-menerus.

- Waktu antara pemesanan sampai dengan pesanan datang (lead time) harus bersifat tetap.

- Tidak pernah ada kejadian persediaan habis.

- Material dipesan dalam paket (lot) dan pesanan datang pada waktu yang bersamaan dan tetap.

- Harga pembelian barang per unit tetap dan tidak ada pengurangan harga walaupun pembelian dalam kuantitas yang besar.

- Besar biaya penyimpanan tergantung secara garis lurus dengan rata-rata jumlah persediaan.

- Besar biaya pemesanan bersifat tetap untuk setiap lot yang dipesan dan tidak tergantung pada jumlah item pada setiap lot.

Rumus yang digunakan untuk menghitung EOQ ditunjukkan pada persamaan (1) [13].

$$
E O Q=\sqrt{\frac{2 x S x D}{H}}
$$

Keterangan:

EOQ: Economic order quantity (dalam unit)

S: Biaya pemesanan dalam satu kali periode pengadaan

D: Jumlah (dalam unit) permintaan selama satu periode

$\mathrm{H}$ : Biaya penyimpanan per unit

Untuk mengetahui jumlah frekuensi pengiriman dengan kuantitas pemesanan yang telah ditentukan maka dapat ditentukan dengan rumus pada persamaan (2) berikut.

$$
f n=\frac{D}{E O Q}
$$

Di mana:

Fn: Frekuensi pengadaan bahan baku

Sedangkan untuk menghitung jumlah kuantitas dari safety stock yang harus dimiliki ialah ditunjukkan pada persamaan (3).

$$
S S=Z x \operatorname{Std} \times L
$$

Di mana:

SS: Safety stock (dalam unit)

Z: Faktor pengali (safety factor)

Std: Standar deviasi jumlah permintaan

L: Lead time

Dalam menentukan besaran dari safety factor dapat ditentukan berdasarkan nilai yang ditunjukkan Tabel 1 [13].
TABEL I

FAKTOR PENGALI DARI SERVICE LEVEL

\begin{tabular}{|l|l|}
\hline Service Level & $\begin{array}{l}\text { Faktor Pengali } \\
\text { (Safety Factor) }\end{array}$ \\
\hline $99,9 \%$ & 3,09 \\
\hline $99,5 \%$ & 2,58 \\
\hline $99 \%$ & 2,33 \\
\hline $97 \%$ & 1,88 \\
\hline $96 \%$ & 1,74 \\
\hline $95 \%$ & 1,64 \\
\hline $90 \%$ & 1,28 \\
\hline
\end{tabular}

Untuk mendapatkan estimasi perkiraan tanggal pengadaan barang, perhitungan dilakukan berdasarkan dari jumlah hari kerja dan total frekuensi pengadaan barang dalam satu periode pengadaan yang telah dihitung sebelumnya. Estimasi perkiraan tanggal untuk pengadaan barang ditentukan dengan menggunakan persamaan (4) berikut [13].

$$
\text { Siklus pemesanan }=\frac{\Sigma \text { hari kerja }}{f n}
$$

Selanjutnya untuk mendapatkan total biaya penyimpanan (total inventory cost) dapat dihitung dengan menggunakan persamaan (5).

$$
T I C=\frac{D x S}{E O Q}+\frac{E O Q \times H}{2}
$$

Di mana:

TIC: Total biaya persediaan (total inventory cost)

\section{Menganalisis Kebutuhan Sistem}

Analisis kebutuhan dilakukan untuk menentukan garis besar sistem yang akan dibangun. Analisis kebutuhan didapatkan merupakan hasil (output) dari proses pengumpulan data. Tahapan analisis kebutuhan menggunakan pendekatan siklus hidup pengembangan sistem atau SDLC (System Development Life Cycle). Model yang digunakan ialah waterfall methodology dengan tujuan untuk mendapatkan proses yang sistematis serta teratur pada pengembangan sistem yang dilakukan. Pada waterfall methodology, proses menganalisis kebutuhan sistem menjadi sangat krusial karena menentukan proses pada perancangan dan implementasi sistem yang dibangun.

\section{Merancang Sistem}

Perancangan sistem merupakan proses yang dilakukan untuk menghasilkan rancangan dari sistem yang sesuai dengan hasil identifikasi analisis kebutuhan sistem pada tahapan sebelumnya. Perancangan sistem secara umum dilakukan meliputi perancangan perangkat keras (hardware) dan perancangan perangkat lunak (software). Perancangan sistem dilakukan menggunakan instrumen Unified Modelling Language (UML). UML yang digunakan pada penelitian ini terdiri dari 2 diagram, yaitu class diagram dan use case diagram. 


\section{E. Mengimplementasikan Sistem}

Implementasi dilakukan untuk mengubah perancangan sistem yang telah dilakukan menjadi output, yaitu suatu sistem yang terprogram serta terintegrasi untuk menjalankan fungsionalitas yang telah dianalisis spesifikasi kebutuhannya. Tahapan implementasi ini terbagi menjadi 2 proses yaitu pemrograman sistem (website dan modul WiFi ESP8266) dan membuat rangkaian RFID yang terdiri dari RFID reader module MFRC522 dan WiFi ESP8266 module.

\section{F. Menguji Sistem}

Sistem yang telah dibangun selanjutnya dilakukan pengujian untuk mengetahui serta memastikan apakah sistem telah memenuhi kebutuhan yang telah diidentifikasi dan dianalisis sebelumnya. Tahapan pengujian sistem meliputi pengujian perangkat keras dan pengujian perangkat lunak. Pengujian perangkat keras dilakukan untuk memastikan bahwa rangkaian RFID bekerja sebagaimana mestinya sesuai dengan fungsi yang ingin dicapai yaitu melakukan otomatisasi pencatatan pergerakan stok masuk dan/atau keluar dari gudang penyimpanan vaksin. Sedangkan pengujian perangkat lunak dilakukan dengan menggunakan black box testing dan performance testing untuk memastikan bahwa inventory system yang dibangun telah sesuai dengan spesifikasi kebutuhan.

\section{HASIL DAN PEMBAHASAN}

Bagian ini menguraikan analisis spesifikasi kebutuhan sistem, perancangan sistem, implementasi, dan pengujian terhadap sistem yang dibangun.

\section{A. Analisis Kebutuhan Sistem}

Menganalisis kebutuhan merupakan proses yang sangat penting dalam tahapan System Development Life Cycle (SDLC). Analisis kebutuhan sistem diperlukan untuk menjadi arah sistem yang dibangun. Analisis kebutuhan didapatkan dari hasil dalam pengumpulan data pada pihak terkait untuk mengetahui proses bisnis sistem inventory yang sedang berjalan saat ini pada puskesmas. Sistem inventori yang dibangun smart inventory system dengan kebutuhan sistem yang diperlukan sebagai berikut.

- Kemudahan mengontrol persediaan stok vaksin yang dimiliki puskesmas untuk efisiensi petugas dalam proses stock opname.

- Kemudahan mengontrol pergerakan stok vaksin yang masuk dan keluae pada vaccine refrigerator.

- Mengidentifikasi kuantitas serta frekuensi pengadaan yang optimal dengan meminimumkan total inventory cost dalam satu periode, estimasi perkiraan tanggal pengadaan, dan mengidentifikasi jumlah safety stock vaksin yang harus dimiliki oleh puskesmas dengan menerapkan metode EOQ.

- Otomatisasi pencatatan serta pelaporan stok masuk dan keluar dari dan/atau ke inventory vaksin yang direkap setiap bulan dengan mengimplementasikan teknologi RFID berbasis IoT.

\section{B. Deskripsi Perancangan Sistem}

Perancangan sistem dilakukan berdasarkan dari hasil spesifikasi kebutuhan sistem yang dibangun. Sistem yang dirancang terdiri dari komponen-komponen yang saling berkaitan. Perancangan sistem dilakukan dengan menggambarkan arsitektur sistem, diagram visualisasi dengan instrumen Unified Modelling Language (UML), dan prototype rangkaian RFID.

Arsitektur sistem merupakan sekumpulan dari modelmodel terhubung yang menggambarkan komponenkomponen lebih spesifik secara terstruktur Berikut ini adalah perancangan arsitektur sistem yang dibangun pada penelitian ini dapat dilihat pada Gambar 3.

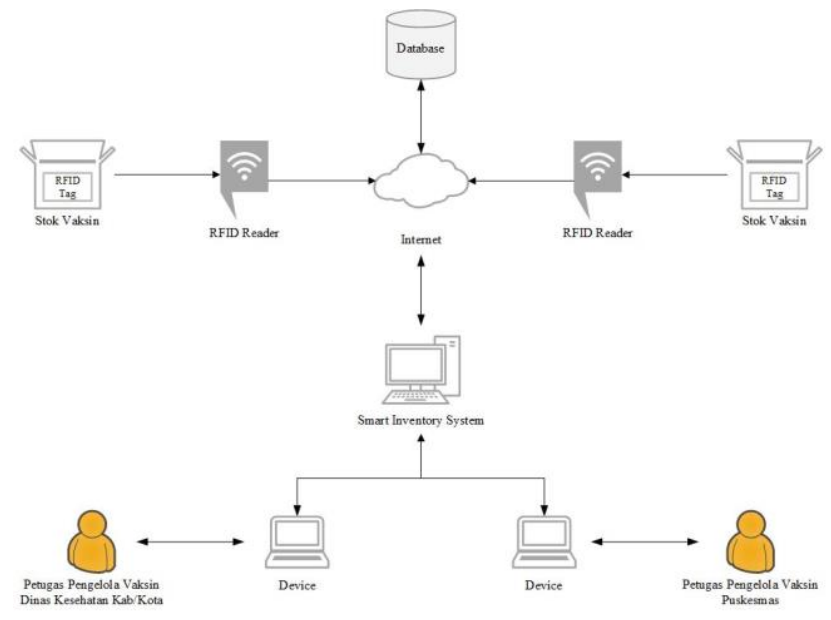

Gambar. 3 Arsitektur sistem

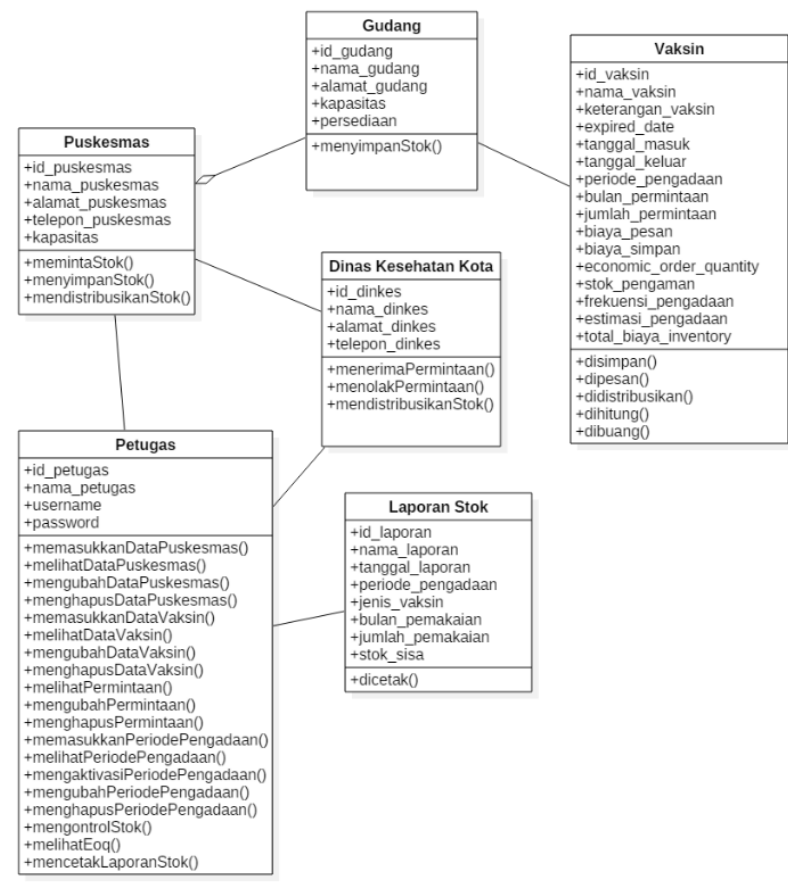

Gambar. 4 Class diagram

Class diagram adalah salah satu dari jenis-jenis diagram UML yang merupakan diagram yang menunjukkan 
hubungan antar kelas, uraian secara detail tiap-tiap kelas di dalam model desain dari suatu sistem yang dirancang, dan memperlihatkan aturan-aturan serta tanggung jawab entitas yang menentukan perilaku sistem [16]. Berikut dapat dilihat pada Gambar 4 merupakan class diagram sistem yang dibangun yang terdiri dari 6 kelas.

Use case diagram merupakan diagram pemodelan visual yang digunakan untuk merepresentasikan pola interaksi dari keseluruhan aktivitas aktor yang terlibat pada sistem yang dibangun [16]. Use case terdiri dari skenario yang berkaitan dengan kejadian antara aktor dengan sistem. Use case diagram sistem yang dibangun dapat terdiri dari 2 aktor yang terlibat yaitu petugas dinkes dan petugas puskesmas dengan pola interaksi yang terjadi dengan sistem dilihat pada Gambar 5.

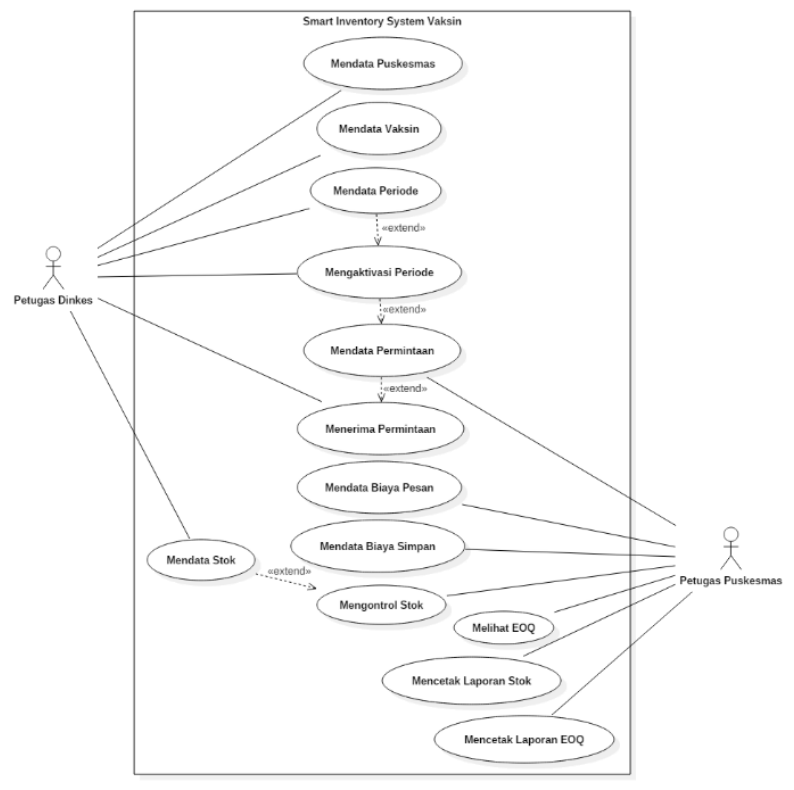

Gambar. 5 Use case diagram

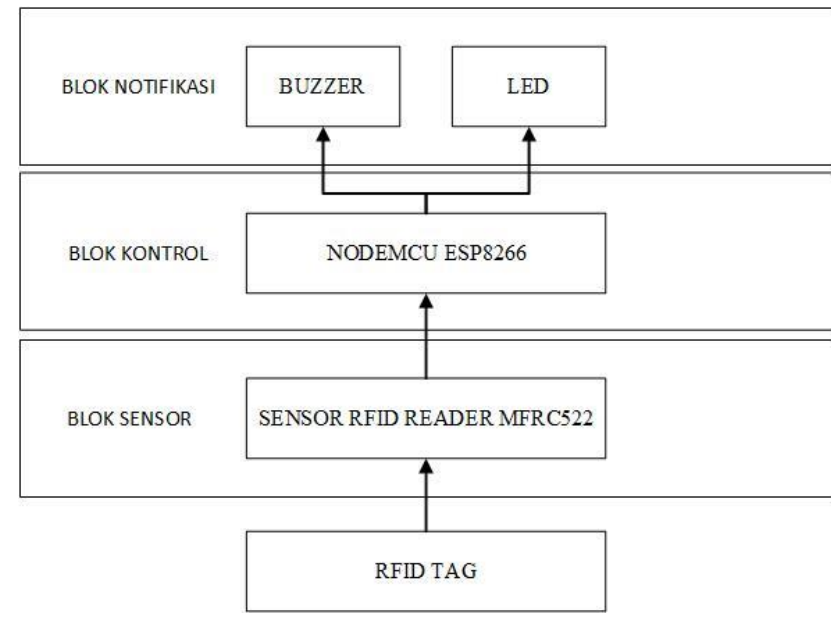

Gambar. 6 Diagram blok alat scan identitas stok

Selanjutnya dilakukan perancangan prototype perangkat keras sebagai komponen dari sistem yang dibangun. Perangkat keras terdiri dari 2 alat, yaitu alat scan identitas stok vaksin yang digunakan petugas dinkes untuk mendata stok vaksin dan alat otomatisasi pencatatan pergerakan stok vaksin untuk puskesmas.

Pertama, perancangan diagram blok prototype alat untuk scan RFID tag yang melekat pada stok vaksin sebagai penyimpan informasi stok dapat dilihat pada Gambar 6 .

Sensor RFID reader yang digunakan untuk alat ini adalah sensor RFID reader MFRC522. Sensor RFID reader MFRC522 akan membaca ID yang melekat pada RFID tag yang kemudian data ID tersebut dikirim ke NodeMCU ESP8266. Skema pengkabelan rangkaian sensor RFID untuk alat scan identitas stok vaksin dapat dilihat pada Gambar 7.

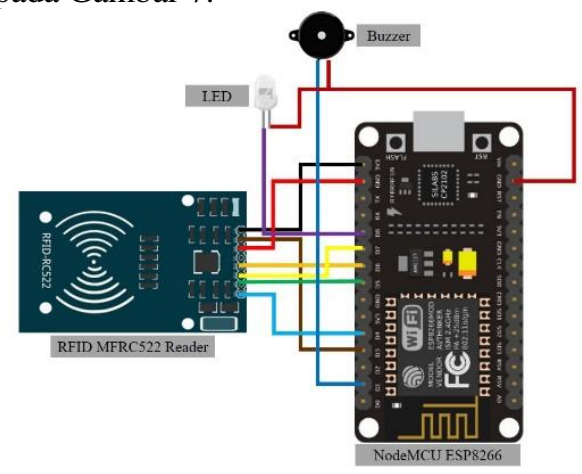

Gambar. 7 Skema pengkabelan alat scan identitas stok

Kedua, perancangan diagram blok prototype alat untuk melakukan pencatatan secara otomatis pergerakan stok vaksin pada gudang dapat dilihat pada Gambar 8.

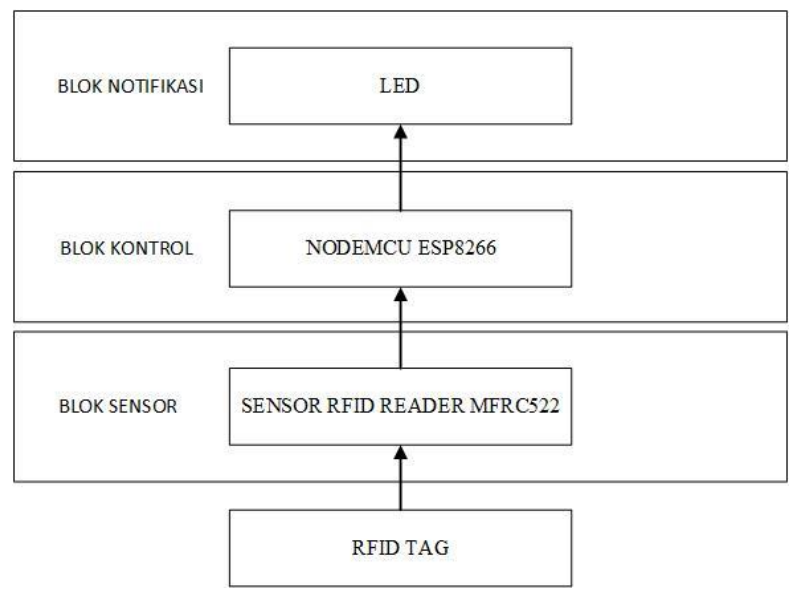

Gambar. 8 Diagram blok alat otomatisasi pencatatan pergerakan stok

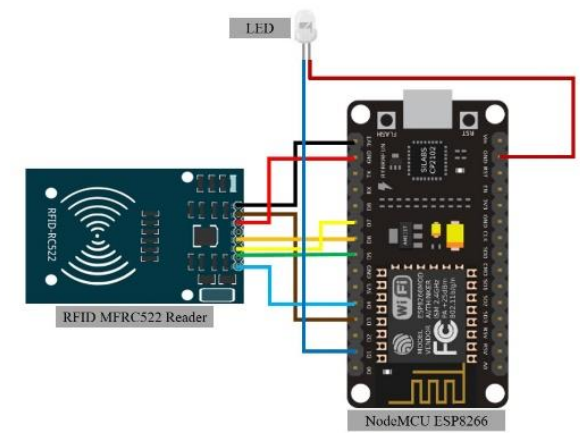

Gambar. 9 Skema pengkabelan alat otomatisasi pencatatan pergerakan stok 
Skema pengkabelan rangkaian sensor RFID untuk alat otomatisasi pencatatan pergerakan stok vaksin pada puskesmas dapat dilihat pada Gambar 9.

\section{Implementasi Sistem}

Implementasi sistem didasarkan pada output pada tahapan perancangan yang telah dilakukan sebelumnya. Implementasi sistem terdiri dari hasil perhitungan pengadaan stok vaksin dengan menggunakan EOQ, prototype perangkat keras, dan perangkat lunak.

Tahapan pertama yang dilakukan adalah mengidentifikasi jumlah pemesanan (pengadaan) stok vaksin yang optimal dengan meminimumkan total inventory cost pada Puskesmas Perumnas II Kota Pontianak dilakukan dengan mengimplementasikan metode Economic Order Quantity (EOQ). Dalam pengimplementasiannya, metode EOQ memerlukan datadata sebagai variabel perhitungan yang meliputi data jumlah permintaan stok, biaya pemesanan, dan biaya penyimpanan untuk masing-masing setiap jenis vaksin yang didistribusikan oleh Puskesmas Perumnas II Kota Pontianak. Pada perhitungan EOQ yang dilakukan pada kasus pengadaan dan pendistribusian stok vaksin pada Puskesmas Perumnas II Kota Pontianak terdapat beberapa yang menjadi parameter untuk mendapatkan standar kuantitas pengadaan stok vaksin yang optimal dengan uraian sebagai berikut.

- Lead Time pendistribusian stok vaksin dari Dinas Kesehatan Kota Pontianak ke puskesmas selama 1 hari kerja.

- Service level yang ditetapkan sebesar 99,9\%, sehingga faktor pengali (safety factor) sebesar 3,09.

- Jumlah hari kerja 365 hari.

Data jumlah permintaan stok setiap bulan tahun 2020 untuk masing-masing jenis vaksin pada wilayah kerja Puskesmas Perumnas II Kota Pontianak dapat dilihat pada Tabel 2 berikut.

TABEL III

DATA PERMINTAAN STOK VAKSIN

\begin{tabular}{|l|l|l|l|l|l|l|}
\hline \multirow{2}{*}{ Bulan } & \multicolumn{7}{l}{ Permintaan } \\
\cline { 2 - 7 } & HB -U & BCG & TD & C & P & DPT \\
\hline Januari & 100 & 15 & 10 & 0 & 40 & 50 \\
\hline Februari & 100 & 15 & 0 & 0 & 40 & 60 \\
\hline Maret & 100 & 10 & 0 & 60 & 20 & 20 \\
\hline April & 100 & 10 & 0 & 0 & 20 & 20 \\
\hline Mei & 100 & 15 & 0 & 0 & 10 & 20 \\
\hline Juni & 100 & 15 & 0 & 15 & 20 & 30 \\
\hline Juli & 100 & 18 & 0 & 15 & 40 & 60 \\
\hline Agustus & 100 & 20 & 0 & 25 & 40 & 50 \\
\hline September & 100 & 10 & 0 & 5 & 20 & 20 \\
\hline Oktober & 100 & 15 & 10 & 0 & 20 & 20 \\
\hline November & 100 & 10 & 5 & 10 & 30 & 30 \\
\hline Desember & 100 & 10 & 10 & 10 & 20 & 30 \\
\hline Total & 1000 & 163 & 35 & 140 & 320 & 410 \\
\hline
\end{tabular}

Keterangan: HB-U $=$ HB UNIJEC; $\mathrm{C}=$ Campak; $\mathrm{P}=$ Polio; $\mathrm{DPT}=\mathrm{DPTHB}-\mathrm{Hib}$
Hasil dari perhitungan pengadaan stok vaksin dalam satu periode pengadaan pada wilayah kerja Puskesmas Perumnas II Kota Pontianak dapat dilihat pada Tabel 3.

TABEL IIIII

HASIL PERHITUNGAN EOQ

\begin{tabular}{|l|l|l|l|l|}
\hline Vaksin & $\begin{array}{l}\text { EOQ } \\
\text { (Unit) }\end{array}$ & Fn & $\begin{array}{l}\text { Estimasi } \\
\text { Pengadaan }\end{array}$ & $\begin{array}{l}\text { Safety Stock } \\
\text { (Unit) }\end{array}$ \\
\hline HB & 524 & 2 & $02-01-2020$ & 90 \\
\cline { 4 - 5 } UNIJEC & & & $06-06-2020$ & \\
\hline BCG & 212 & 1 & $02-01-2020$ & 11 \\
\hline TD & 98 & 1 & $02-01-2020$ & 14 \\
\hline Campak & 196 & 1 & $02-01-2020$ & 54 \\
\hline Polio & 297 & 2 & $02-01-2020$ & 34 \\
& & & $06-06-2020$ & \\
\hline $\begin{array}{l}\text { DPTHB- } \\
\text { Hib }\end{array}$ & 336 & 1 & $02-01-2020$ & 51 \\
\hline
\end{tabular}

Sehingga didapatkan berdasarkan dari perhitungan yang ditujukkan pada Tabel 3 total inventory cost stok vaksin dalam satu periode pengadaan pada tahun 2020 Puskesmas Perumnas II Kota Pontianak dapat dilihat pada Tabel 4 berikut.

TABEL IVV

TOTAL INVENTORY COST STOK VAKSIN

\begin{tabular}{|l|l|}
\hline Vaksin & Total Inventory Cost $(\mathbf{R p )}$ \\
\hline HB UNIJEC & 458.258 \\
\hline BCG & 185.014 \\
\hline TD & 85.732 \\
\hline Campak & 171.464 \\
\hline Polio & 292.230 \\
\hline DPTHB-Hib & 293.429 \\
\hline Total Cost (Rp) & 1.453 .127 \\
\hline
\end{tabular}

Berdasarkan perhitungan yang dilakukan dengan menggunakan metode Economic Order Quantity (EOQ), maka didapatkan Total Inventory Cost (TIC) untuk semua jenis vaksin dalam satu periode pengadaan yaitu pada tahun 2020 yang didistribusikan oleh Puskesmas Perumnas II Kota Pontianak adalah sebesar Rp1.453.127.

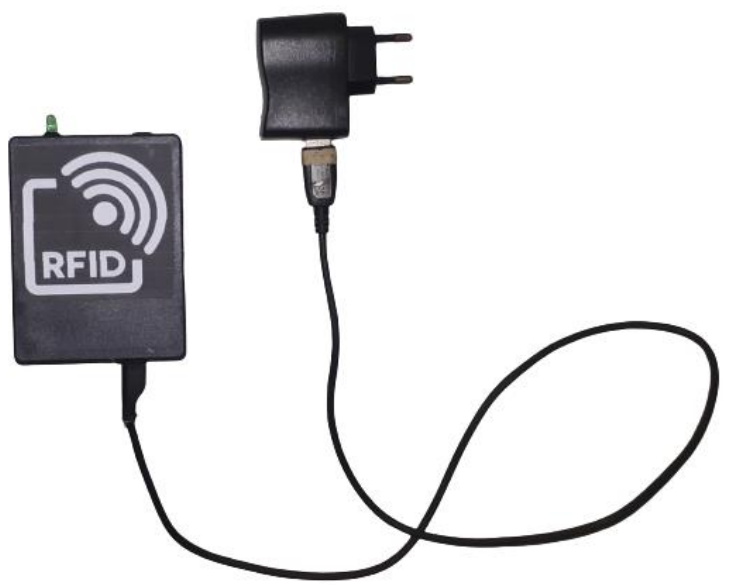

Gambar. 10 Prototype alat scan identitas stok

Tahapan kedua yang dilakukan adalah mengimplementasikan rangkaian prototype perangkat keras dari sistem yang dibangun. Pada Gambar 10 
merupakan hasil implementasi dari perancangan rangkaian perangkat keras yang digunakan untuk alat scan RFID tag pada stok vaksin sebagai identitas stok vaksin.

Sedangkan pada Gambar 11 hasil implementasi dari perancangan rangkaian perangkat keras yang digunakan untuk alat otomatisasi pencatatan pergerakan stok vaksin pada puskesmas. Alat ini dipasang di pintu masuk/keluar gudang tempat penyimpanan vaksin pada puskesmas sehingga dapat mencatat pergerakan stok masuk dan keluar stok vaksin.

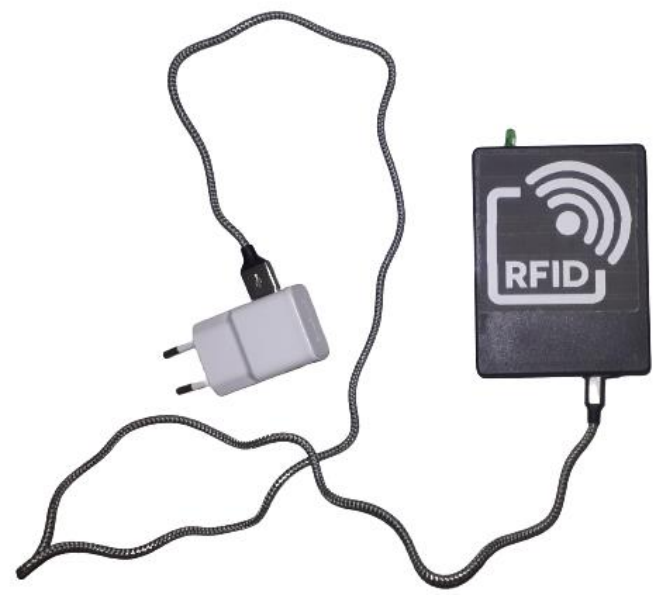

Gambar. 11 Prototype alat otomatisasi pergerakan stok

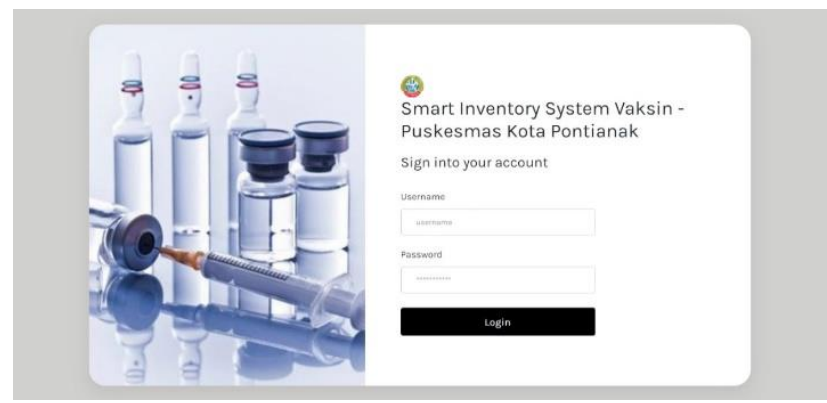

Gambar. 12 Halaman login petugas puskesmas

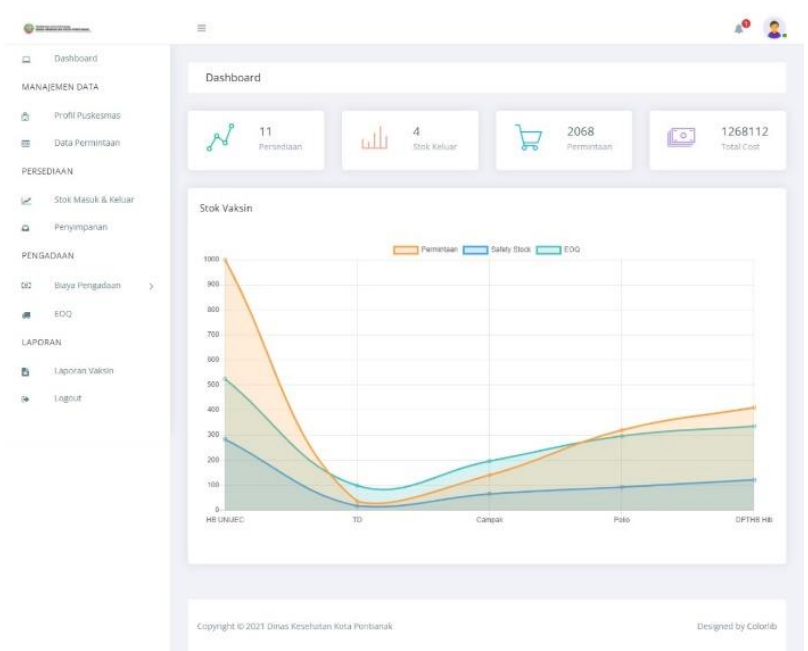

Gambar. 13 Halaman dashboard petugas puskesmas
Tahapan ketiga yang dilakukan adalah mengimplementasikan perangkat lunak sistem yang dibangun. Pada Gambar 12 merupakan tampilan antarmuka halaman login petugas puskesmas. Jika petugas berhasil melakukan login selanjutnya petugas secara otomatis masuk ke halaman dashboard (Gambar 13) yang memuat informasi secara umum mengenai smart inventory system.

Tampilan antarmuka halaman data permintaan stok vaksin yang digunakan petugas untuk memasukkan data permintaan stok vaksin dalam satu periode dapat dilihat pada Gambar 14 berikut.

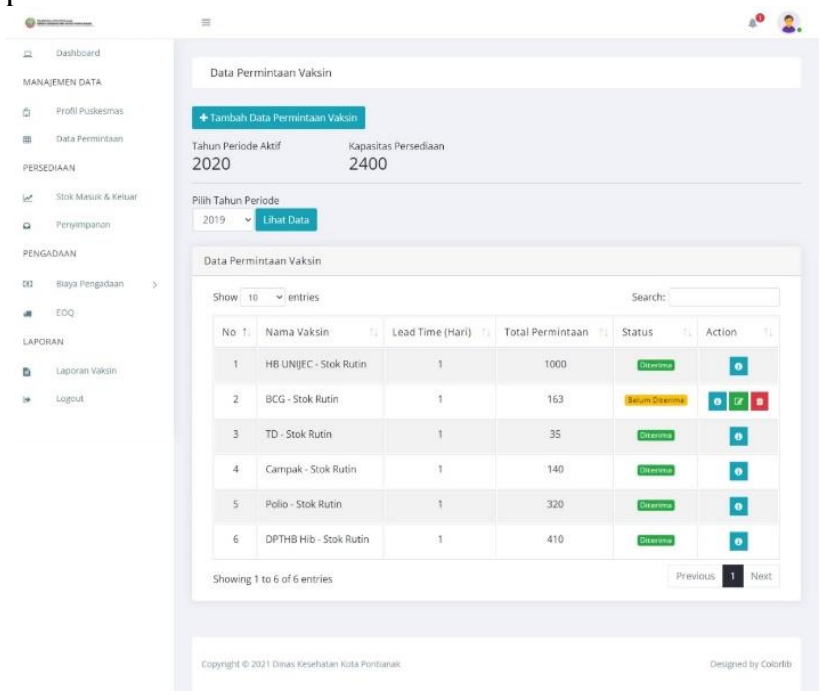

Gambar. 14 Halaman data permintaan stok

Selanjutnya, tampilan antarmuka halaman stok masuk dan keluar dapat dilihat pada Gambar 15. Pada halaman ini petugas puskesmas dapat mengontrol pergerakan stok vaksin pada vaccine refrigerator.

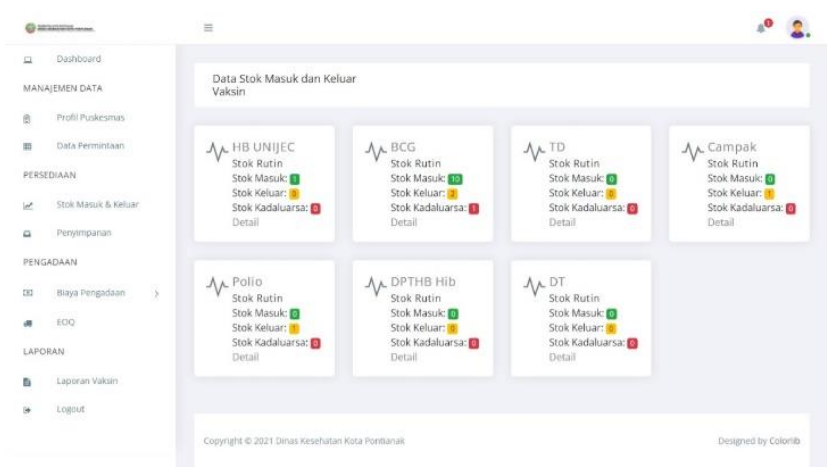

Gambar. 15 Halaman pergerakan stok masuk dan keluar

Tampilan antarmuka halaman monitoring stok vaksin yang tersedia dan status ketersediaan stok tersebut pada vaccine refrigerator pada puskesmas dapat dilihat pada Gambar 16. 


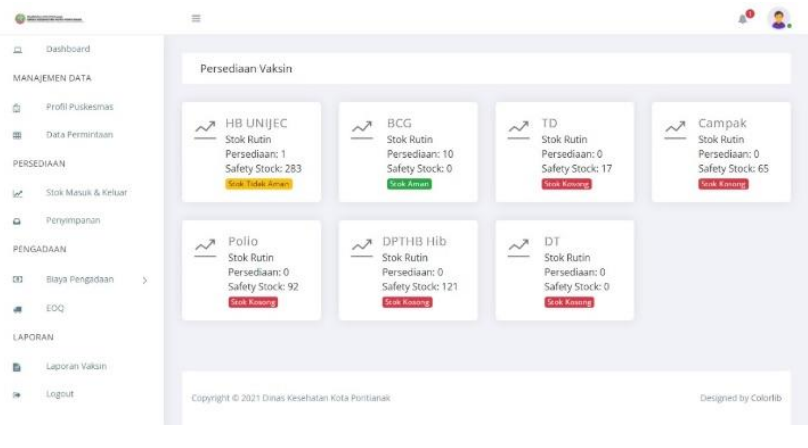

Gambar. 16 Halaman persediaan stok puskesmas

Tampilan antarmuka halaman EOQ merupakan halaman yang menampilkan informasi hasil perhitungan EOQ pada proses pengadaan stok vaksin dalam satu periode yang sedang aktif dapat dilihat pada Gambar 17.

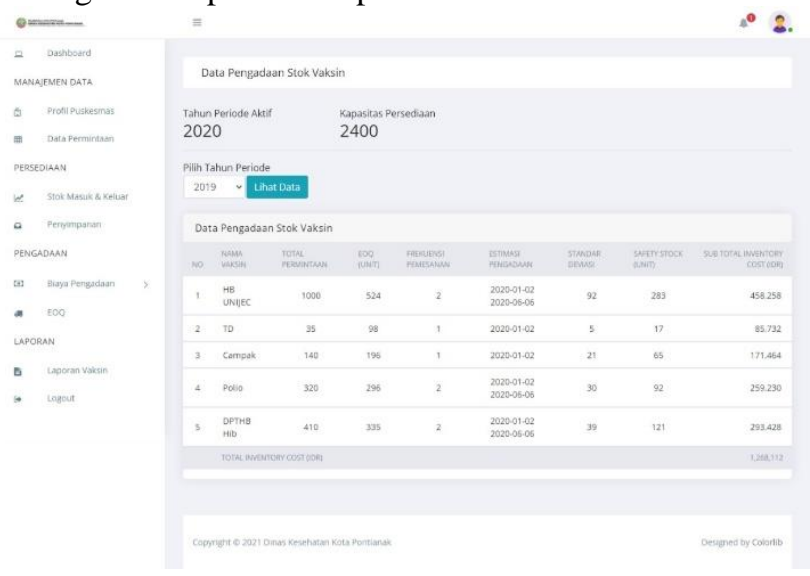

Gambar. 17 Halaman hasil perhitungan EOQ

\section{Pengujian Sistem}

Pengujian sistem dilakukan dari 2 sisi komponen dalam smart inventory system yaitu pada perangkat keras maupun perangkat lunak. Pengujian perangkat lunak dilakukan dengan menggunakan metode black box testing dan performance testing.

Tahapan pertama dari pengujian sistem yaitu pengujian terhadap perangkat keras dilakukan untuk mengetahui apakah rangkaian prototype perangkat keras yang telah dibangun bekerja dengan fungsionalitas yang diinginkan. Rangkaian perangkat keras yang diuji meliputi rangkaian modul WiFi NodeMCU ESP8266, pembaca RFID MFRC522, buzzer, dan lampu LED. Pengujian pada modul WiFi NodeMCU ESP8266 dilakukan untuk mengetahui apakah modul tersebut dapat mengirimkan data yang telah dibaca oleh pembaca RFID ke server database sistem. Sedangkan pengujian modul pembaca RFID MFRC522 dilakukan untuk mengetahui apakah pembaca RFID dapat membaca informasi pada tag RFID atau tidak. Berdasarkan hasil pengujian pada rangkaian perangkat keras secara umum, hasil pengujian ditunjukkan pada Tabel 5 .
TABEL V

Hasil Pengujian PERANGKat KeRAS

\begin{tabular}{|l|l|l|l|}
\hline Pengujian & Test Case & $\begin{array}{l}\text { Hasil yang } \\
\text { Diharapkan }\end{array}$ & Hasil \\
\hline $\begin{array}{l}\text { NodeMCU } \\
\text { ESP8266 }\end{array}$ & $\begin{array}{l}\text { Memperoleh data } \\
\text { sensor RFID }\end{array}$ & $\begin{array}{l}\text { Menampilkan } \\
\text { data sensor } \\
\text { yang terbaca }\end{array}$ & Berhasil \\
\hline $\begin{array}{l}\text { NodeMCU } \\
\text { ESP8266 }\end{array}$ & $\begin{array}{l}\text { Menghubungkan } \\
\text { ke jaringan WiFi }\end{array}$ & $\begin{array}{l}\text { Terhubung ke } \\
\text { jaringan } \\
\text { internet }\end{array}$ & Berhasil \\
\hline $\begin{array}{l}\text { NodeMCU } \\
\text { ESP8266 }\end{array}$ & $\begin{array}{l}\text { Upload data hasil } \\
\text { sensor ke } \\
\text { database }\end{array}$ & $\begin{array}{l}\text { Data } \\
\text { tersimpan di } \\
\text { database }\end{array}$ & Berhasil \\
\hline $\begin{array}{l}\text { MFRC522 } \\
\text { RFID } \\
\text { Reader }\end{array}$ & Scan RFID tag & $\begin{array}{l}\text { Dapat } \\
\text { membaca } \\
\text { RFID tag }\end{array}$ & Berhasil \\
\hline $\begin{array}{l}\text { LED dan } \\
\text { Buzzer }\end{array}$ & $\begin{array}{l}\text { Menyala dan } \\
\text { mati }\end{array}$ & $\begin{array}{l}\text { Dapat } \\
\text { menyala dan } \\
\text { mematikan } \\
\text { otomatis }\end{array}$ & Berhasil \\
\hline
\end{tabular}

Selanjutnya tahapan kedua dilakukan pengujian terhadap perangkat lunak sistem yang dibangun. Pertama, pada Tabel 6 merupakan hasil dari pengujian black box. Pengujian black box dilakukan dengan mengeksekusi setiap unit atau modul pada sistem yang telah dibangun dengan suatu masukkan (input) tertentu, setelahnya diamati apakah hasil dari keluaran (output) eksekusi tersebut telah berhasil dan telah sesuai dengan fungsionalitas yang diinginkan.

TABEL VI

Hasil PENGUJiAn BLACK BOX TESTING

\begin{tabular}{|c|c|c|}
\hline Pengujian & Input Data & Hasil Pengujian \\
\hline \multirow{3}{*}{$\begin{array}{l}\text { Mendata } \\
\text { Permintaan } \\
\text { Stok }\end{array}$} & Data kosong & Data tidak tersimpan \\
\hline & Data salah $(<0)$ & Data tidak tersimpan \\
\hline & $\begin{array}{l}\text { Data Benar } \\
(100000<= \\
\text { permintaan }<=0)\end{array}$ & $\begin{array}{l}\text { Data dapat tersimpan } \\
\text { oleh sistem }\end{array}$ \\
\hline \multirow{3}{*}{$\begin{array}{l}\text { Mendata } \\
\text { Biaya Pesan } \\
\text { dan Biaya } \\
\text { Simpan }\end{array}$} & Data kosong & Data tidak tersimpan \\
\hline & $\begin{array}{l}\text { Data salah (biaya } \\
<1000 \text { ) }\end{array}$ & Data tidak tersimpan \\
\hline & $\begin{array}{l}\text { Data benar }(1000 \\
<=\text { biaya }<= \\
100000000)\end{array}$ & $\begin{array}{l}\text { Data dapat tersimpan } \\
\text { oleh sistem }\end{array}$ \\
\hline $\begin{array}{l}\text { Menghitung } \\
\text { dan } \\
\text { Memvalidasi } \\
\text { Hasil EOQ }\end{array}$ & Data benar & $\begin{array}{l}\text { Sistem menghitung } \\
\text { EOQ dengan benar } \\
\text { dan sesuai }\end{array}$ \\
\hline \multirow[t]{3}{*}{$\begin{array}{l}\text { Mencatat } \\
\text { Pergerakan } \\
\text { Stok }\end{array}$} & $\begin{array}{l}\text { Status stok = } \\
\text { "Stok Dinkes" }\end{array}$ & $\begin{array}{l}\text { Status menjadi "Stock } \\
\text { In" dan tanggal masuk } \\
\text { dicatat }\end{array}$ \\
\hline & $\begin{array}{l}\text { Status stok = } \\
\text { "Stock In" }\end{array}$ & $\begin{array}{l}\text { Status menjadi "Stock } \\
\text { Out" dan tanggal } \\
\text { keluar dicatat }\end{array}$ \\
\hline & $\begin{array}{l}\text { Status stok = } \\
\text { "Stock Out" }\end{array}$ & $\begin{array}{l}\text { Status menjadi "Stock } \\
\text { In" dan tanggal masuk } \\
\text { dicatat }\end{array}$ \\
\hline
\end{tabular}


Kedua, dilakukan pengujian perangkat lunak dengan metode performance testing. Performance testing adalah pengujian non-fungsional yang dilakukan dengan tujuan untuk mengukur serta mengevaluasi ketahanan dan kinerja unit atau modul dari sistem baik bagian dari modulmodulnya maupun secara keseluruhan [17]. Performance testing yang dilakukan pada penelitian ini berfungsi untuk menganalisis efisiensi penggunaan arsitektur sistem yang telah dirancang sebelumnya dan algoritma yang ditulis pada program sistem. Performance testing dilakukan dengan mensimulasikan fungsionalitas utama dari sistem oleh perilaku end-user melalui web browser user yang direkam dengan menggunakan extension Blazemeter. Selanjutnya, hasil rekaman simulasi oleh user tersebut digenerate oleh test generator secara otomatis dengan menggunakan tools Apache Jmeter. Pengujian ini dilakukan dengan masukkan (input) parameter pengujian yang meliputi number of threads sebanyak 30 virtual users, ramp-up periode sebesar 1 detik, dan loop count sebanyak 1 kali. Berdasarkan dari hasil performance testing yang dilakukan, didapatkan hasil kinerja dari smart inventory system yang telah dibangun seperti yang ditunjukkan pada Tabel 7 berikut.

TABEL VII

Hasil Pengujian PERFoRMANCE TESTING

\begin{tabular}{|l|l|l|l|l|l|}
\hline Sample & $\begin{array}{l}\text { Min } \\
(\mathbf{m s})\end{array}$ & $\begin{array}{l}\text { Max } \\
(\mathbf{m s})\end{array}$ & $\begin{array}{l}\text { Error } \\
(\%)\end{array}$ & $\begin{array}{l}\text { Throu } \\
\text { ghput }\end{array}$ & $\begin{array}{l}\text { Send } \\
\text { Kb/Sec }\end{array}$ \\
\hline 30 & 96 & 117 & 1,98 & $3.0 / \mathrm{sec}$ & 142,62 \\
& & 672 & & & \\
\hline
\end{tabular}

\section{KESIMPULAN}

Smart inventory system untuk distribusi vaksin yang dikembangkan ini dengan menggunakan pendekatan System Development Life Cycle (SDLC) dimana terdiri dari proses-proses logika untuk menyelesaikan permasalahan yang kemudian untuk menjawab kebutuhan sistem yang dibangun. Dalam pengimplementasiannya SDLC memerlukan suatu model, dalam penelitian ini model yang digunakan yaitu waterfall methodology yang dimana model ini merupakan model dengan berurutan dari atas ke bawah yang bergerak secara teratur sehingga memudahkan dalam mengklasifikasikan tugas yang dilakukan serta proses pendokumentasian menjadi lebih terorganisir. Tahapan dalam pengembangan smart inventory system ini terdiri dari proses menganalisis kebutuhan sistem, merancang sistem dengan menggunakan instrumen UML, mengimplementasikan sistem, dan pengujian.

Smart inventory system yang dibangun menerapkan metode Economic Order Quantity (EOQ) yang dapat meningkatkan kinerja sistem dan membantu petugas puskesmas dalam mengambil keputusan terkait proses pengadaan stok vaksin yang lebih optimal sehingga dapat meminimalkan total biaya penanganan persediaan. Selain itu, sistem ini juga dengan menerapkan teknologi RFID yang berbasis IoT sebagai otomatisasi pencatatan pergerakan stok vaksin di puskesmas yang dapat mencapai sinkronisasi dan akurasi data sehingga meningkatkan kinerja, pengendalian, dan efisiensi petugas puskesmas dalam proses stock opname.

Sistem ini kemudian diuji dan didapatkan bahwa fungsionalitas dari setiap proses dalam smart inventory system dapat berjalan dengan baik, meliputi proses mengirim permintaan stok vaksin oleh puskesmas, menerima atau menolak permintaan stok vaksin oleh dinas kesehatan kabupaten/kota, monitoring persediaan stok vaksin pada puskesmas, otomatisasi pencatatan pergerakan stok masuk dan/atau keluar dari dan/atau ke vaccine refrigerator, dan mencetak laporan stok vaksin yang direkap setiap bulan.

\section{REFERENSI}

[1] D. Kurniawan, R. Andrian, and N. Y. Utami, "Sistem Inventory Jurusan Ilmu Komputer di Universitas Lampung," Jurnal Komputasi, vol. 2, pp. 18-26, 2016.

[2] J. Jeniffer, G. M. Ashfaq, L. Deekshitha, Venkateshappa, and K. B. Franklin, "Smart Inventory Management Shelve Using Neural Network and Google Cloud," International Journal of Advanced Science and Technology, vol. 29, pp. 4410-4420, 2020.

[3] M. Maksuk, "Pengelolaan Rantai Dingin Vaksin Tingkat Puskesmas di Kota Palembang Tahun 2011," Jurnal Kesehatan Poltekkes Palembang, vol. 1, pp. 94-100, 2012.

[4] D. A. Nurrahma and A. Y. Ridwan, "Usulan Perencanaan Kebijakan Persediaan Vaksin Menggunakan Metode Continuous Review (S,S) untuk Mengurangi Overstock di Dinas Kesehatan Kota XYZ," Jurnal Rekayasa Sistem \& Industri, vol. 3, pp. 47-51, April 2016

[5] S. L. Munira, Penyediaan Obat, Vaksin, dan Alat Kesehatan. Jakarta: Direktorat Kesehatan dan Gizi Masyarakat Kedeputian Pembangunan Manusia, Masyarakat dan Kebudayaan Kementerian PPN/Bappenas, 2019.

[6] A. S. Rwashana, and D. W. Williams, "Enhancing Immunization Healthcare Delivery Through The Use of Information Communication Technologies," Strengthening the Role of ICT in Development, pp. 144-156, 2007.

[7] B. Riyanto, Dasar-Dasar Pembelanjaan Perusahaan. Yogyakarta: BPFE, 2001.

[8] K. K. G. Santhosh and P. Jayarekha, "Smart Inventory Management System," International Education \& Research Journal (IERJ), vol. 3, pp. 514-516, May 2017.

[9] K. Sebastian, S. Suakanto, and M. Hutagalung, "Penerapan RFID untuk Pencatatan Inventory Barang di dalam Gudang," Jurnal Telematika, vol. 12, pp. 161-167, 2017.

[10] M. L. Hamzah and A. A. Purwati, "Sistem Manajemen Inventori Komputer Menggunakan Near Field Communication Berbasis Android (Studi Kasus di STIE Pelita Indonesia Pekanbaru)," Journal of Economic, Business, and Accounting (COSTING), vol. 1, pp. 95-104, December 2017.

[11] A. Eroglu and G. Ozdemir, "An Economic Order Quantity Mode with Defective Items and Shortages," International Journal of Production Economics, vol. 106, pp. 544-549, April 2007.

[12] J. Heizer and B. Render, Manajemen Operasi. Jakarta: Salemba Empat, 2010.

[13] N. Apriyani and A. Muhsin, "Analisis Persediaan Bahan Baku dengan Metode Economic Order Quantity dan Kanban pada PT Adyawinsa Stamping Industries," Jurnal Optimasi Sistem Industri. vol. 10, pp. 128-142, December 2017.

[14] T. Iqbal, D. Apriezal, and M. Wali, "Aplikasi Manajemen Persediaan Barang Berbasis Economic Order Quantity (EOQ)," Jurnal JTIK (Teknologi Informasi dan Komunikasi), vol. 1, pp. 4960, June 2017.

[15] M. Prasetyawati, U. Marfuah, and G. Wijaya, "Usulan Pengendalian Kebutuhan Persediaan Menggunakan Metode Economic Order Quantity di PT. Indotruck Utama Cabang Jakarta,' Spektrum Industri, vol. 15, pp. 79-92, 2017.

[16] A. Hendini, "Pemodelan UML Sistem Informasi Monitoring Penjualan dan Stok Barang (Studi Kasus: Distro Zhezha 
Pontianak)," Jurnal Khatulistiwa Informatika, vol. 4, pp. 107-116, December 2016.
[17] J. Agnihotri and P. Rashmi, "Development of Performance Testing Suite Using Apache JMeter," Intelligent Computing and Information and Communication, vol. 673, pp. 317-326, 2018. 